\title{
O PROCESSO DE INSTALAÇÃO DO REGIME DE LOJA FRANCA EM CORUMBÁ/MS (UMA CIDADE EM ZONA DE FRONTEIRA): DILEMAS E POSSIBILIDADES
}

\section{THE INSTALLING PROCESS OF THE DUTY-FREE SHOP REGIME IN CORUMBÁ-MS (A TOWN IN FRONTIER ZONE): DILEMMAS AND POSSIBILITIES}

Roberto Mauro da Silva Fernandes ${ }^{1}$

RESUMO: O objetivo do presente artigo é refletir sobre o processo de instalaçăo do Regime Aduaneiro de loja franca no município de Corumbá/MS. Deste modo, no foco de nossa discussāo está na Zona de Fronteira Brasil/Bolívia. Trata-se, sobretudo, de uma análise a respeito de como as instâncias de planejamento do Município de Corumbá/ MS e alguns segmentos sociais estăo se articulando politicamente no sentido de criar instrumentos regulatórios para o comércio (varejista) numa zona fronteiriça caracterizada por relaçôes internacionais cotidianas. Para tal, fizemos uso de levantamento bibliográfico e realizamos trabalho de campo na cidade em referência.

PALAVRAS-CHAVE: Zona de Fronteira. Lojas Francas. Brasil. Bolívia. Território.

\begin{abstract}
The purpose of this paper is to reflect about the installing process of the Customs Regime of duty-free shop in Corumbá-MS, Brazil. Thereby, the focus of our discussion is in the Frontier Zone Brazil/Bolivia. It is, above all, an analysis of how the planning instancies of the municipality of Corumbá/MS, and some social segments are articulating politically in the sense of creating regulatory instruments for trade (retailer) in a frontier zone characterized by daily international relations. In order to do so, we made use of literature review and fieldwork in the referred city.
\end{abstract}

KEYWORDS: Frontier Zone. Duty-free shops. Brazil. Bolivia. Territory.

1 Pós-Doutorando em Geografia pela Universidade Estadual do Centro-Oeste - UNICENTRO (Paraná), Doutor em Geografia pela Universidade Federal da Grande Dourados, mestre em Geografia pela Universidade Federal da Grande Dourados e graduado em História pela Universidade Federal de Mato Grosso do Sul. roberto_mauro.78@hotmail.com 


\section{INTRODUÇÃO}

De acordo com a Portaria $n^{0}$ 125, de 21 de março de 2014, do Ministério da Integraçăo Nacional, cidades-gêmeas săo aqueles municípios cortados pela linha de fronteira, seca ou fluvial, articulada ou náo por obra de infraestrutura, conurbada ou semi-conurbada, com localidade de país vizinho que apresentem grande potencial de integraçăo econômica, cultural e manifestaçôes "condensadas" dos problemas característicos da fronteira (BRASIL, 2014).

Mediante isso, as cidades-gêmeas săo àquelas que melhor representam a Zona de Fronteira, esta que é composta pelas faixas territoriais de cada lado do limite internacional estatal "[...] caracterizada por interaçōes que criam um meio geográfico próprio de fronteira, somente perceptível na escala local/regional das interaçōes transfronteiriças" (BRASIL, 2005, p. 152). Oficialmente săo vinte e nove as cidades classificadas como gêmeas ao longo da extensa fronteira terrestre brasileira.

Deste modo, no estado (UF) de Mato Grosso do Sul está localizada a Zona de Fronteira Brasil/Bolívia, composta pelas cidades brasileiras de Corumbá/MS e Ladário/MS, bem como, por Puerto Quijarro (seu distrito Arroyo Concepción) e Puerto Suárez, urbes da Província de Germán Busch do Estado Plurinacional da Bolívia². Tais centros săo caracterizados por intercâmbios nas áreas de educaçăo, saúde, segurança, meio ambiente, lazer e, sobretudo, no comércio.

Comumente, os moradores de Puerto Suárez e Puerto Quijarro utilizam os serviços de saúde e matriculam suas crianças e adolescentes em escolas no "lado"3 brasileiro daquela fronteira. Os cidadăos bolivianos também atuam profissionalmente em Corumbá/MS e Ladário/MS, bem como, os centros comerciais instalados nos municípios bolivianos sâo assídua e cotidianamente frequentados por brasileiros para consumo e trabalho. Portanto, as pessoas que vivem na fronteira em questăo interagem elaborando seus códigos básicos de sobrevivência e de convivência para além dos limites estatais estabelecidos para delimitar o "território"4.

As cidades em questăo, portanto, apresentam estreitas relaçóes. Logo, bolivianos e brasileiros protagonizam movimentos que ultrapassam as "linhas" oficiais, produzindo relaçôes que se baseiam, em grande parte dos casos, em suas referências socioespaciais. De igual modo, convivem com códigos jurídicos que os definem como nacionais dos seus respectivos Estados, reforçando os laços de pertencimento e identificaçáo

2 Na fronteira terrestre entre Brasil e Bolívia encontram-se três Zonas de Fronteiras, formadas por oito cidades-gêmeas. Além daquelas que estăo localizadas em Mato Grosso do Sul/Província de Gérman Busch, as demais săo: Brasiléia/AC - Cobija (Departamento de Pando), Guajará-Mirim/RO - Guayaramerin, no Departamento de Beni (BRASIL, 2005, p. 149-150; BRASIL, 2010, p. 22).

3 O substantivo "lado" será apresentado com aspas, pois é uma provocaçăo de nossa parte. As cidadesgêmeas possuem dinâmicas que văo para além dos limites estabelecidos. A infixidez das gentes nesses espaços internacionais é cotidiana e os deslocamentos e as relaçóes pessoais năo săo impedidos pelas barreiras estatais.

4 Neste caso, fazemos referência ao aspecto jurídico, que aponta os limites cartográficos para demarcar países, municípios, cidades, etc. Assim, quando nos referirmos ao "território" desta maneira, sempre o faremos com aspas. Quando utilizarmos território sem aspas, estaremos aludindo ao meio geográfico dotado de relaçôes de poder, definidas pelos ordenamentos cotidianos (que estâo além dos jurídicos e cartográficos), pelas questóes políticas, econômicas e sociais, por processos de apropriaçáo e dominaçáo e, especialmente, como espaço imprescindível para a reproduçăo social. 
com "territórios" dessemelhantes em meio a um contexto espacial que também năo "guarda bandeiras" e tampouco "lados".

Desta maneira, o objetivo deste artigo é refletir acerca do processo de instalaçăo do Regime Aduaneiro de loja franca no município de Corumbá/MS, mais especificamente, nossas análises tem como ponto de partida a publicaçáo do Decreto municipal $n^{\circ}$ 1.432/2014, que dispôs sobre a criaçăo de Grupo de Trabalho que tem como escopo pensar açôes visando à implantaçăo do regime no município em questăo.

Para obtençăo do que nos propomos a realizar, utilizamo-nos de levantamento bibliográfico e trabalho de campo na cidade de Corumbá/MS que consistiu em entrevistar, entre junho de 2015 e janeiro de 2018, aqueles diretamente envolvidos com as dinâmicas transfronteiriças de comércio. Além desta introduçāo, o artigo contém outras três seçôes. Na seçáo primeira apresentamos uma discussăo sobre a publicaçâo Lei $n^{\circ} 12.723 / 2012$, que versa sobre o Regime Aduaneiro Especial de Loja Franca em fronteira terrestre. No secionamento segundo, advogamos a respeito das dinâmicas relacionadas a implantaçâo do regime de lojas francas em Corumbá/MS a partir da publicaçăo do Decreto municipal n 1.432/2014. O último segmento reservamos para nossas consideraçóes finais.

\section{A LEI 12.723/2012 E A PORTARIA N 307/2014: LOJAS FRANCAS [FREE SHOPS] PARA AS CIDADES-GÊMEAS}

No dia 09 de outubro de 2012 foi sancionada a lei 12.723 que autorizou a instalaçăo de lojas francas em municípios caracterizados como cidades-gêmeas. A lei é resultante do Projeto de Lei n 6.316/2009, proposto pelo Deputado Federal Marco Maia.

No ano de 2012 o projeto foi renumerado para PL n 11/2012 e encaminhado para o Senado, em abril de 2012 a Presidência do Senado comunicou o recebimento do projeto e determinou que fosse encaminhado para as Comissóes de Relaçóes Exteriores e Defesa Nacional e Comissáo de Assuntos Econômicos. No dia 12 de setembro de 2012, a última aprovou o projeto, voltando para a Câmara dos Deputados para ser votado em plenário, sendo aprovado no dia 18 de setembro de 2012 e sancionado pela Presidenta Dilma Rousseff em 09 de outubro de 2012 (SILVA e PRADO, 2014, p. 501/502).

A sançăo da Lei n 12.723/2012 gerou grande expectativa. Nas declaraçóes públicas, a institucionalidade era apresentada como soluçáo para acarretar ganhos econômicos e ao mesmo tempo ampliar a concorrência brasileira no comércio das cidades-gêmeas. Para alguns parlamentares e outros sujeitos envolvidos com o comércio em municípios de fronteira, as cidades estrangeiras praticavam uma concorrência desleal (AUTOR, 2015, p. 194).

A regulamentaçâo da lei 12.723/2012 ocorreu por meio da Portaria MF nº 307, de 17 de julho de 2014, que dispóe sobre a aplicaçaáo do regime aduaneiro especial de loja franca em fronteira terrestre. Deste modo, ficou autorizada a venda de mercadoria nacional ou estrangeira, com isençấo de tributos, a pessoa em viagem terrestre internacional. Além disso, o artigo $6^{\circ}$ estabeleceu que: a) é necessária lei municipal que autorize a instalaçăo do regime de lojas francas; b) os estabelecimentos interessados em participar do regime devem comprovar valor de patrimônio líquido mínimo ou prestar 
garantia em valor equivalente; c) haverá implementaçâo de sistema informatizado de controle de entrada, estoque e saída de mercadorias, d) deve existir no município uma unidade, serviço, seçâo ou setor da Receita Federal com competência para proceder ao controle aduaneiro (BRASIL, 2014(b)).

A Portaria $n^{\circ} 307 / 2014$ também alterou o artigo $7^{\circ}$ da Portaria $n^{\circ} 440 / 2010^{5}$. Houve a diminuiçấo da quantia de US\$ 300,00 para US\$ 150,00 da cota anteriormente estabelecida para compra de produtos sem pagamento de tributos por via terrestre (BRASIL, 2014(b)). A alteraçấo causou certa surpresa nos sujeitos envolvidos com o comércio das cidades-gêmeas. Em Foz de Iguaçu, o Prefeito Reni Pereira asseverou:

Recebemos a notícia como um presente de Grego. Ao mesmo tempo em que podemos abrir as lojas francas, baixaram a cota. A gente sabe que parte do dinheiro que circula aqui, principalmente nos bairros, vem desse turismo de compras. Falta de respeito com Foz do Iguaçu (RADIOCULTURA, 2014).

A Portaria $n^{\circ} 307 / 2014$ foi posteriormente alterada pela Portaria MF n³20, de 22 de julho de 2014: "Art. $3^{\circ}$. Fica restabelecida a vigência da redaçăo original da alínea «b» do inciso III do art. $7^{\circ}$ da Portaria MF n 440 de 30 de julho de 2010" (BRASIL, 2014(c)). Isto é, a cota para consumo, sem tributaçăo, por via terrestre voltava a ser no valor de US\$ 300,00, assim como, ficou estabelecido com a publicaçấo da nova normativa que o artigo 22 da n $^{\circ}$ 307/2014 entraria em vigor somente em 01 de julho de 2015. De acordo com o secretário da Receita Federal, o Sr. Carlos Alberto Barreto:

Vamos prorrogar a vigência do que hoje existe em termos de cota (US\$ 300 via terrestre) por năo menos de 6 meses. Mas deve ser em torno de um ano. Depende de autorizaçăo de cada município onde văo funcionar [as lojas francas], de sistemas de preparaçăo dos investidores $(\mathrm{G} 1,2014)$.

A intençăo da Receita Federal, aparentemente, era aguardar até que as Lojas Francas estivessem em funcionamento. Entretanto, tal protelaçâo năo estava relacionada apenas aos fatores destacados pelo servidor público. Como o artigo $6^{\circ}$ da Portaria $n^{\circ}$ 307/2014, parágrafo IV, estabelece como uma das condiçôes e requisitos para o funcionamento das lojas francas a implantaçăo de sistema informatizado para controle de entrada, saída, estoque, registro e apuraçăo das mercadorias e créditos tributários, a operabilidade dos free shops também estava condicionada a confecçâo do software para viabilizar as operaçóes do referido sistema. Isso se confirmou com a publicaçăo da Portaria MF $n^{0} 415$, de 26 de junho de 2015. Lê-se no artigo $1^{\circ}$ :

Art. 1ㅇ 0 art. 24 da Portaria MF no 307, de 17 de julho de 2014, passa a vigorar com a seguinte redaçăo:

"Art. 24. Esta Portaria entra em vigor a partir da data de sua publicaçáo no Diário Oficial da Uniâo, exceto o seu art. 22, que entra em vigor a partir:

I - de 1ํ de julho de 2016; ou No que tange a Portaria $n^{\circ} 440$, a normativa alterou a forma de contabilizar os bens trazidos na bagagem
para uso pessoal, estabelecendo uma cota limite para o viajante, equivalente a US\$ 500,00 (por via aérea) e US\$ 300,00 (por via terrestre) com isençâo de tributos. (BRASIL, 2010). 
II - do 1ํ(primeiro) dia do 3ํ(terceiro) mês subsequente à implementaçáo do sistema de controle informatizado previsto no inciso IV do $\S 2^{\circ}$ do art. $6^{\circ}$ acompanhada da ediçăo do ato da Secretaria da Receita Federal do Brasil referido no art. 23, se anterior à data estabelecida no inciso I." (NR) (BRASIL, 2015).

O documento prorrogou por mais um ano a entrada em vigor do artigo 22 da Portaria $n^{\circ} 307 / 2014$, que consequentemente havia alterado o artigo $7^{\circ}$ da Portaria $n^{0}$ 440/2010, isto é, da cota de US\$ 150,00 para compra de produtos sem pagamento de tributos por via terrestre. Assim como, sinalizou um prazo para a estruturaçâo do sistema informatizado que vai dar suporte para os trâmites realizados nas Lojas Francas.

O sistema em referência será viabilizado por meio do desenvolvimento de um software que permitirá o controle da emissâo de tickets de venda. A Receita Federal está adotando um modelo de fiscalizaçăo eletrônica automática que vai possibilitar que o viajante ao adquirir produtos nas Lojas Francas năo necessite se encaminhar a Unidade da Receita Federal para declarar as suas compras. Assim, nas ocasióes em que adquirir produtos, o comerciante que atua nos free shops acessará o sistema da Receita Federal e pedirá autorizaçâo para emissăo do ticket, deste modo, haverá o controle da cota e o pagamento da mercadoria.

De igual modo, caso o turista/viajante ultrapassar os US\$ 150, 00 previstos, efetuará pagamento com o próprio vendedor no estabelecimento (produtos acima da cota sâo tributados no regime especial, ou seja, $50 \%$ no que exceder. Isto está disposto nos artigos 101 e 102 do Decreto n 6.759, de 5 de fevereiro de 2009). Portanto, o consumidor sairá da loja com a obrigaçāo tributária já cumprida e năo precisará se encaminhar a órgâo aduaneiro ou fiscal para realizar nenhum procedimento (CANAL 10 RIVERA, 2014).

Destarte, a prorrogaçăo entabulada na Portaria MF n 415/2015 estava relacionada, aparentemente, a confecçâo do software, pois ao contrário do que relatou o secretário da Receita Federal, o Sr. Carlos Alberto Barreto, o funcionamento das Lojas Francas independe da definiçăo de "onde" tais estabelecimentos vâo funcionar, visto o sistema de fiscalizaçâo ser eletrônico e automático.

Entretanto, o sistema informatizado năo foi operacionalizado como o previsto, logo, a Receita Federal manteve a cota de US\$ 300,00 para compra no exterior por via terrestre. A orientaçăo está plasmada no artigo $1^{\circ}$ da Portaria MF n²89, de 30 de junho de 2016. Neste sentido, por mais um ano, a reduçăo para compra no exterior de US\$̦ 150,00 foi adiada. A previsăo ficou para $1^{\circ}$ de julho de 2017 (BRASIL, 2016). Passado o período, uma nova instruçâo foi publicada, a Portaria MF n 307, de 29 de junho de 2017, que mais uma vez prorrogou para $1^{\circ}$ de julho de 2018 a entrada em vigor do artigo n 22 da Portaria MF n 307/2014.

\section{DECRETO MUNICIPAL N ${ }^{\circ} 1.432$ E O REGIME ESPECIAL DE LOJA FRANCA EM CORUMBÁ/MS}

Em relaçăo ao processo de funcionamento das lojas francas no município de Corumbá/MS, no dia 21 de outubro de 2014 foi publicado o Decreto municipal n ${ }^{\circ} 1.432$ e foi sancionada a Lei $n^{\circ} 2.498$, de 25 de agosto de 2015 . O primeiro dispôs sobre a criaçăo de Grupo de Trabalho que tinha como escopo pensar açôes visando à implantaçâo 
do regime e o segundo édito versa sobre a instalaçâo de lojas francas no Município de Corumbá/MS (deliberaçáo que está de acordo com o artigo $6^{\circ}$, inciso $\mathrm{I}$, da Portaria $\mathrm{n}^{\circ}$ 307/2014).

Entretanto, os impasses e preocupaçóes perseveravam, em parte, por conta da percepçăo macroterritorial da Receita Federal e por outro lado pelo "olhar" parcial dos gestores e demais entidades de classe corumbaenses acerca do local onde vivem e trabalham, pois pensam o processo de instalaçăo do regime aduaneiro de Lojas Francas de modo que seja vantajoso apenas para os comerciantes brasileiros, o que consequentemente é um problema, já que năo há como planejar e implantar políticas no "lado" brasileiro sem dialogar com e considerar vantagens para o "lado" boliviano daquela fronteira.

Deste modo, nesta seçăo, vamos apontar as principais resistências no que tange ao processo que visa instalar o regime de lojas francas em Corumbá/MS.

\subsection{PARTICIPAÇĀO DE AMBOS OS “LADOS” DA FRONTEIRA?}

No dia 21 de outubro de 2014 foi publicado o Decreto municipal nº 1.432 que dispôs sobre a criaçấo de Grupo de Trabalho para discussăo, organizaçăo e criaçăo de um plano de açâo visando à implantaçăo do regime de Loja Franca no município de Corumbá/MS. Nos artigos $2^{\circ}$ e $3^{\circ}$ do documento é possível ler:

Art. $2^{\circ} \mathrm{O}$ Grupo de Trabalho terá a seguinte composiçăo:

I - um representante da Secretaria Municipal de Indústria e Comércio, na qualidade de coordenador;

II-umrepresentante doSindicato do Comércio Varejista de Corumbá-SINDVAREJO;

III - um representante da Associaçăo Comercial e Industrial de Corumbá - ACIC.

Art. $3^{\circ} \mathrm{O}$ Grupo de Trabalho poderá ser composto, ainda, por representantes das seguintes instituiçôes convidadas:

I - um representante do Poder Legislativo Municipal;

II - um representante da Agência Fazendária Estadual (AGENFA);

III - um representante da Receita Federal do Brasil;

IV - um representante do Departamento de Polícia Federal;

V - um representante da Federaçáo do Comércio do Estado de Mato Grosso do Sul (FECOMERCIO);

VI - um representante da Federaçăo das Associaçōes Comerciais do Estado de Mato Grosso do Sul (FAEMS);

VII - um representante da Camara de Industria, Comercio y Servicio da Provincia German Bush - Bolívia (MATO GROSSO DO SUL , 2014, p. 1). 
No que concerne ao artigo $3^{\circ}$, observamos uma incoerência. Năo há mençâo aos órgâos públicos e as entidades/organizaçôes vinculadas ao setor de comércio da cidade de Puerto Quijarro/Arroyo Concepción. A "Camara de Industria, Comercio y Servicio da Provincia German Bush" é uma entidade da cidade Puerto Suárez. Por que Puerto Quijarro/Arroyo Concepción năo săo indicadas? Nessas urbes encontram-se os principais centros comerciais daquela Zona de Fronteira, ademais inúmeros cidadâos bolivianos que nelas residem, trabalham na cidade de Corumbá/MS.

A participaçâo dos comerciantes e do Poder Público de Puerto Quijarro/Arroyo Concepción é de extrema relevância, sobretudo, no que diz respeito à criaçấo de diretrizes que possam mitigar os confrontos de classe no setor e possibilitar discussóes sobre futura produçáo de harmonizaçōes legislativas que contemplem os dois "lados" da fronteira. Pensamos que é impossível discutir a instalaçăo de lojas francas e as consequências de tal estratégia de comércio (especialmente no que se refere a geraçâo de empregos) sem envolver a classe trabalhadora boliviana do "outro lado".

Bem como, o édito náo faz referência ao Núcleo Regional de Integraçáo da Faixa de Fronteira do Mato Grosso do Sul (NFMS), instituído pelo Decreto estadual n 13.303, de 22 de novembro de 2011. Os Núcleos Regionais sâo instâncias de planejamento para a Faixa de Fronteira que fazem parte do arcabouço institucional pensado pelo Grupo de Trabalho Interfederativo de Integraçăo Fronteiriça (GTI), coordenado pelo Ministério da Integraçáo Nacional e criado pelo Comitê de Articulaçáo Interfederativa (CAF) da Secretaria de Relaçóes Institucionais (SRI) da Presidência da República, por meio da Resoluçăo nº 08, de 19 de Novembro de 2008.

O GTI foi prescrevido em 2010 para atualizar os dados do Programa de Desenvolvimento da Faixa de Fronteira (PDFF), elaborado no ano 2005; e consequentemente confeccionou outro relatório contendo propostas que tem por objetivo fomentar o desenvolvimento e a articulaçâo de açôes de integraçăo fronteiriça. Entre as asserçôes do documento está o estabelecimento da Comissāo Permanente de Desenvolvimento e Integraçấo da Faixa de Fronteira (CDIF), um colegiado composto por representantes de órgâos federais e estaduais.

Logo, para a execuçấo dos objetivos traçados foi engendrada a seguinte composiçăo: a) uma Secretaria Executiva (SE), cuja direçăo ficou a cargo da Coordenaçăo-Geral do Programa de Promoçâo do Desenvolvimento da Faixa de Fronteira da Secretaria de Programas Regionais do Ministério da Integraçāo Nacional, b) Núcleos Regionais (NR), compostos de instituiçóes que tenham relevância para o desenvolvimento e integraçăo fronteiriços, em nível local ou regional e c) de Grupos Técnicos (GT), para temas complexos como segurança, circulaçăo de pessoas, comércio internacional, etc. (BRASIL, 2010, p. 79-80).

De acordo com o documento elaborado pelo GTI (Bases para uma Proposta de reestruturaçăo do Programa de Desenvolvimento da Faixa de Fronteira), a existência dos Núcleos Regionais "[...] é essencial para o sucesso da CDIF, na medida em que propicia a articulaçăo das políticas setoriais com as características particulares de cada fronteira e permite o aprimoramento do diálogo federativo numa dada regiăo" (BRASIL, 2010, p. 79).

Os Núcleos Regionais săo o elo entre os sujeitos locais e a Secretaria Executiva e, entre outras coisas, responsáveis por colher e sistematizar as demandas locais e 
articular soluçóes de âmbito local e regional para as diligências identificadas (BRASIL, 2010). No caso do Núcleo Regional de Integraçăo da Faixa de Fronteira do Mato Grosso do Sul, sua coordenaçâo ficou a cargo da Secretaria de Estado de Meio Ambiente, do Planejamento, da Ciência e Tecnologia (SEMAC) e da Secretaria de Desenvolvimento Agrário, da Produçâo, da Indústria, do Comércio e do Turismo (SEPROTUR). Portanto, um desses órgáos estaduais (ou representantes dos dois) deveria compor o Grupo de Trabalho estatuído para discutir a implantaçăo do Regime de Loja Franca em Corumbá/MS.

Sendo o NFMS a conexăo entre as cidades da Faixa de Fronteira sul-mato-grossense e a Secretaria Executiva da CDIF, aquele poderia ser acionado pelos órgáos públicos corumbaenses no sentido de requerer a criaçăo de Grupo Técnico para colaborar na elaboraçăo, implantaçăo, acompanhamento e promoçăo de projetos específicos relacionados ao tema, sendo o instrumento para analisar e referendar as propostas do NFMS. É preciso informar que estas sâo, conforme as propostas do GTI, algumas das responsabilidades e competências destinadas à instância. Assim como, o liame Grupo Técnico - NFMS - Grupo de Trabalho seria fundamental na confrontaçâo entre moçóes locais (produzidas com o andamento do GT sobre Loja Franca) e entre as proposituras do Plano de Desenvolvimento e Integraçăo da Faixa de Fronteira/MS, este elaborado pelo NFMS 6 .

A criaçăo da CDIF é um avanço relevante, pois possibilita aos governos subnacionais discutir diretamente com os órgâos superiores a formalizaçáo e implantaçáo de ossatura jurídica que dê sustentaçăo as suas atuaçôes no plano externo. Assim, é dever dos gestores municipais acionar tal instância.

É necessário sublinhar que sem tal arcabouço jurídico, os governos municipais e estaduais brasileiros tendem a protagonizar movimentos complementares à diplomacia do Estado. Nos últimos vinte anos, aqueles vêm realizando inúmeras açóes no ambiente internacional que sâo de facto e nâo de jure. Esta diplomacia complementar ${ }^{7}$ é de facto, pois a Constituiçăo brasileira é categórica quanto aos papéis de atuaçăo dos agentes e entidades no ambiente internacional ${ }^{8}$.

6 Destaca-se que o Plano de Desenvolvimento e Integraçâo da Faixa de Fronteira/MS, publicado no ano de 2012, foi desdobramento da criaçâo do CDIF e do NFMS.

7 Rodrigo de Oliveira Perpétuo afirma que éinoportuna einadequada a noçáo de que os governos municipais e estaduais realizam açôes paradiplomáticas, haja vista năo utilizarem rotas alternativas ou paralelas de diplomacia estatal, mas sim participarem da mesma rota dos Estados-Naçáo, de forma complementar, especialmente, pois os governos subnacionais nâo rompem com as definiçôes tradicionais da diplomacia moderna que tendem "[...] a ser baseadas em três princípios: a) a conduçăo de relaçôes pacíficas; b) entre estados mutuamente reconhẹcidos e soberanos; c) em expectativas de relaçôes de longo prazo" (PLUIJM; MELISSEN, 2007 apud PERPÉTUO, 2014, p. 89).

8 A Carta Magna brasileira apresenta no artigo 21, inciso I, que compete a Uniâo "[...] manter relaçôes com Estados estrangeiros e participar de organizaçôes internacionais". No artigo 25, parágrafo $1^{\circ}$, lế-se: "Săo reservadas aos Estados as competências que náo lhes sejam vedadas por esta Constituiçấo", ou seja, a Uniâo cabe matérias e questôes de interesse geral, no que tange ao artigo 30, inciso I, cabe aos municípios "[...] legislar sobre assuntos de interesse local" (no caso das cidades-gêmeas as questôes internacionais sâo assuntos de interesse local, é preciso destacar). Outro dispositivo constitucional a ser ressaltado é o artigo 52, inciso V, que permite ao Senado Federal "[...] autorizar operaçóes externas de natureza financeira, de interesse da Uniâo, dos Estados, do Distrito Federal, dos Territórios e dos Municípios". E por fim, pode-se ler no artigo 84, incisos VII e VIII, que é competência privativa do presidente da república manter relaçōes com Estados estrangeiros, acreditar seus representantes diplomáticos, celebrar tratados, convençóes e atos internacionais. 
Os governos subnacionais vêm atuando diretamente no plano externo por meio de assessorias e secretarias internacionais em outros países, sem a intermediaçâo do Itamaraty e de outras instâncias do Poder Executivo. De acordo com Sombra Saraiva (2006): “Governadores viajam, muitas vezes, com mais objetividade e mais bem preparados para a negociaçăo de interesses comerciais do que membros do governo central [...]" (SOMBRA SARAIVA, 2006, p. 447).

Logo, a Comissāo Permanente de Desenvolvimento e Integraçăo da Faixa de Fronteira (CDIF) contribuiria para oficializar os costumes internacionais já praticados por governadores das Unidades Federativas e prefeituras. Os entendimentos estabelecidos entre as instâncias da CDIF com as cidades da Faixa de Fronteira, especialmente às cidades-gêmeas, podem agregar novos dispositivos formais para respaldar as operaçōes internacionais dos governos subnacionais, aliando-os as demais normas que versam sobre planejamento urbano, ambiental, infraestrutural, etc., inclusive inserindo tais regras na Constituiçăo Federal.

Quando o GTI pensou a CDIF, delegou às instâncias que a compóe a realizaçăo de atividades que visem pensar e propor políticas com concepçóes do tipo Top-down (de cima para baixo) e Botton-up (de baixo para cima). O que significa dar aos municípios autonomia para se articularem na escala do território e apresentar às demandas as instâncias responsáveis (NR e SE). Mediante o feedback, os sujeitos locais săo condicionados a agir. Esse "agir" depende de questôes da cena política ${ }^{9}$, orçamentárias e do corpo técnico das administraçôes subnacionais.

No que concerne às questôes partidárias, é necessária a articulaçâo dos sujeitos municipais com o Parlamento estadual e/ou no Congresso Nacional para que os apontamentos realizados no âmbito local sejam institucionalizados, isto é uma característica na estrutura constitucional brasileira. As articulaçōes na cena política sâo de suma importância porque vâo possibilitar a instrumentalizaçăo das sinergias orçamentárias descritas no documento "Bases para uma Proposta de reestruturaçăo do Programa de Desenvolvimento da Faixa de Fronteira" que prevê a realizaçáo das propostas apresentadas seja se estiverem no interior do que prevê a constituiçăo e/ou no caso de náo haver recursos federais, visto apontar alinhamentos com agências nacionais e organismos internacionais (públicos e privados) no sentido de captar recursos.

No que diz respeito ao corpo técnico, a CDIF provoca as administraçōes públicas da Faixa de Fronteira a pensarem em novos mecanismos de planejamento, gestăo compartilhada (TORRENCILHA, 2013) e de participaçăo popular que sejam compatíveis com territórios dotados de relaçōes internacionais.

No que concerne ao distanciamento dos governos subnacionais com os órgăos federais, este afastamento pode ser relativizado, isso depende de como os agentes locais vâo se movimentar para sensibilizar as instâncias superiores, o que pode definir se a participaçāo dos primeiros é pequena ou nâo. O arcabouço institucional criado (CAF, GTI, CDIF, SE, NR e GT) possibilita grande participaçăo dos municípios, haja vista serem eles os responsáveis por apresentar as particularidades do território aos órgáos

9 De acordo com Nicos Poulantzas (2000), a cena política está relacionada à estrutura política partidária e trata-se de elemento de suma importância no contexto de relaçóes de forças que alicerçam o Estado e fundamental nas articulaçóes do bloco no poder. 
federais e, sobretudo, convocar o debate. Assim, é de extrema importância que ambos os "lados" da fronteira participem.

A CDIF estabelece uma subordinaçăo aos governos subnacionais, pensamos que tal relaçâo é positiva, àqueles, embora tenham catas específicas, săo elementos constituintes do Estado (do "território" especificamente), mediante as conjunturas políticas as açōes paralelas (paradiplomacia) podem ser construídas a revelia dos interesses estatais. As políticas pensadas para as cidades fronteiriças, dentro de suas singularidades, devem estar concordadas a esfera macroterritorial, isto é, as Políticas Nacionais. Por exemplo, os esforços na Zona de Fronteira Brasil/Bolívia, devem conciliar políticas locais, regionais e nacionais de Brasil e Bolívia.

\subsection{TURISTAS OU ESTRANGEIROS: VENDER PARA QUEM?}

O artigo $5^{\circ}$ do Decreto municipal n ${ }^{\circ}$ 1.432/2014 versa sobre as atribuiçôes do Grupo de Trabalho que estava encarregado da realizaçấo de a) reuniōes com os representantes das instituiçóes e órgâos envolvidos e pela proponência de atribuiçóes aos mesmos; b) à realizaçăo de estudos para avaliar a viabilidade de instalaçăo das lojas francas em Corumbá/MS; c) pelos diálogos necessários a criaçăo do Plano de Açăo concernente à operaçâo dos free shops na cidade e, de igual modo, d) cabia ao GT criar o Plano de Açâo e propor os métodos de execuçăo após a sua. O documento também especificava o dia 21 de outubro de 2015 como data cabal para o término das estratégias supracitadas: "Art. $6^{\circ} \mathrm{O}$ prazo para conclusâo dos trabalhos do grupo é de 1 (um) ano a contar da data de publicaçăo[21/10/2015] deste Decreto" (MATO GROSSO DO SUL, 2014, p. 1).

Entretanto, de acordo com as informaçôes que obtivemos em nosso trabalho de campo, o Grupo de Trabalho jamais foi operacionalizado. Entre os motivos do náo funcionamento estavam às dúvidas, por parte dos órgăos públicos responsáveis e dos interessados, sobre quem poderia comprar nos estabelecimentos credenciados como free shops. Em setembro de 2015, entrevistamos o entăo Secretário de indústria e Comércio do município de Corumbá/MS, o Sr. Pedro Paulo Marinho, que nos declarou o seguinte:

Nesse momento [29/09/2015] existe um decreto que criou um Grupo de Trabalho, mas ainda năo foi formado [...] Aqui no município nós enxergamos que a questăo dos free shops ainda precisa ser melhorada, a questăo do regulamento, a normativa que saiu [Portaria $\left.n^{\circ} 307 / 2014\right]$. Em conversa com empresários e comerciantes daqui, acreditamos que năo é a melhor forma para se trabalhar, sobretudo porque somente se observa o estrangeiro que tem que estar saindo do país ou que está entrando. Hoje quem entra aqui [Corumbá/MS] e consome é o boliviano da fronteira, acredito que é o nosso grande cliente, os turistas de pesca, também consomem muito na fronteira, também săo brasileiros que vem e năo estăo com a intençấo de sair do país. Entăo, pelo que a normativa "fala", da Receita Federal, eles [viajantes] tem que ter documento hábil de estrangeiro para poder consumir dentro de um free shop. E os comerciantes aqui, a gente também apoia (a parte da prefeitura), é que isso também seja favorável [compra nas lojas franca] para o pessoal daqui, que năo exija essa documentaçăo de estrangeiro e sim que seja controlada, a ideia é que seja controlada pela Receita Federal, por CPF [Cadastro de Pessoa Física] mesmo só no município, que qualquer loja possa usufruir desse benefício fiscal de isençăo e năo só uma 
free shop. A gente enxerga que o turista que tá aqui na cidade, seja o turista de compra, ou aquele que vem contemplar o Pantanal ou pescar. Ele vem năo com a intençấo de sair para o estrangeiro. Hoje a gente tem uma grande dificuldade, por exemplo, você vai sair hoje do país, vai fazer documento de alfândega tem que passar pela Polícia Federal, enfrenta fila de uma hora pra fazer e mais uma hora na parte da Bolívia, entăo você imagina que turista que vem com essa intençăo de compra, pra ficar nessa fila e ir para a Bolívia e para ter um documento hábil e ainda enfrentar tudo isso de retorno justamente para comprar numa free shop, entăo à gente acha que isso inviabiliza a questăo dos free shops como está sendo colocada hoje. Entăo a gente acha que é inviável essa questâo de exigir documentaçăo para poder entrar numa loja e fazer compra como acontece nos aeroportos. A normativa năo oferece qualquer atratividade para se instalar as lojas. Porque se eles exigirem a documentaçăo de estrangeiros, năo vejo esse fluxo de turistas que entra com a intençâo de compra. Quando a populaçăo vai a Bolívia comprar existe a fiscalizaçăo da cota de US\$ 300,00, porém năo se exige documentaçăo para se fazer a compra. E o que a receita quer é que para se comprar no Brasil, em dólar, ele tem que ter o documento fiscal de estrangeiro que ele está entrando no país ou saindo. As cidades que tem comércio na fronteira, no país vizinho năo se exige essa documentaçấo. O brasileiro nâo pode comprar. Essa é uma luta nossa. O turista vem para cá [Corumbá/MS] e acaba indo na Bolívia, consome e năo se exige documento. A gente tem uma pesquisa que no carnaval do ano passado [2014], o consumo na Bolívia foi "em torno" de um milhăo de reais. Entâo o turista que veio para curtir o carnaval, até mesmo o corumbaense gastou isso. Só que năo exigiu documento para ele gastar esse dinheiro ${ }^{10}$.

Mediante tais palavras, percebe-se que o Grupo de Trabalho até entăo náo havia sido instalado (restando apenas vinte dias para o fim do prazo estabelecido no Decreto municipal $n^{\circ} 1.432 / 2014$ ) porque existiam discordâncias, por parte dos envolvidos no processo, quanto ao que estava posto na Portaria $n^{\circ} 307 / 2014$, nesse caso, em relaçâo a quem poderia comprar nas lojas francas.

A interpretaçâo do secretário municipal girava em torno de certa restriçâo que fora estabelecida a respeito do estrangeiro ser o único com possibilidades de adquirir mercadorias nos free shops. No artigo 13 da Portaria n 307/2014 pode-se ler: "Art. 13. Somente poderá adquirir mercadoria de loja franca de fronteira terrestre o viajante que ingressar no País [grifo nosso] e for identificado por documentaçâo hábil" (BRASIL, 2014). Nota-se que no dispositivo năo há qualquer mençâo sobre o comprador ser ou năo ser estrangeiro, o artigo 13 especifica que somente viajantes podem comprar. A nacionalidade năo é critério para qualificar ou desqualificar futuros usuários da tecnologia [free shop].

Em dezembro de 2014, o Sr. Adilson Valente, Inspetor Chefe da Receita Federal em Santana do Livramento/PR (cidade-gêmea que compóe juntamente com Rivera/UR a Zona de Fronteira Brasil/Uruguai), concedeu entrevista a uma emissora uruguaia da cidade de Rivera/UR - CANAL 10 RiveraUY - e ressaltou:

“A lei fala que sâo viajantes, nela nâo há restriçâo sobre a nacionalidade. Entāo tanto os uruguaios, argentinos, quanto os brasileiros poderâo comprar nas lojas francas. Desde que sejam viajantes" (CANAL 10 RIVERA, 2014).

10 Entrevista realizada no dia 29/09/2015. 
Esta é uma referência que faz as cidades-gêmeas de Rivera/ UR e Santana do Livramento/BR e que também cabe às urbes da Zona de Fronteira Brasil/Bolívia e a qualquer outra que possua dinâmicas fronteiriças terrestres de comércio.

Ao dar a declaraçấo, o Inspetor da Receita Federal fazia alusăo ao Decreto-Lei $n^{\circ}$ 1.455, de 7 de abril de 1976, a Lei $n^{\circ} 12.723$, de 2012 e aos artigos 13 e 14 da Portaria ${ }^{\circ}$ 307/2014, a segunda norma altera o artigo 15 da primeira, incluindo o artigo 15-A. No parágrafo $2^{\circ}$ do artigo 15-A está especificado que:

$\S 2^{\circ} \mathrm{A}$ venda de mercadoria nas lojas francas previstas neste artigo somente será autorizada à pessoa física, obedecidos, no que couberem, as regras previstas no art. 15 e demais requisitos e condiçôes estabelecidos pela autoridade competente (BRASIL, 2012).

No paragrafo $2^{\circ}$, de igual modo aos artigos 13 e 14 da Portaria nº 307/2014, náo há mençâo a respeito de venda apenas para estrangeiros e quanto ao artigo 15 do Decreto-Lei $n^{0} 1.455 / 76$, este trata de vendas em lojas francas instaladas em zona primária de portos e aeroportos "[...] a passageiros de viagens internacionais, na chegada ou saída do País, ou em trânsito, contra pagamento em moeda nacional ou estrangeira" (BRASIL, 1976). O que năo se enquadra a free shops em fronteira terrestre. Entretanto, novamente percebe-se que náo se menciona estrangeiro, mas sim passageiros em viagens internacionais, ou seja, pode ser qualquer passageiro, independe a nacionalidade.

A "dúvida" sobre quem poderia realizar compras nas lojas francas, aparentemente, incorria porque no artigo 13 está entabulado que somente terá acesso as novas tecnologias comerciais "[...] o viajante que ingressar no País", bem como, no artigo 14 está especificado que o limite de isençâo (US\$ 300,00) para a venda de mercadoria importada é destinada "[...] ao viajante que ingressar no País". A respeito de tais assertivas, o Inspetor da Receita Federal, a o ser questionado sobre a possibilidade do morador de Santana de Livramento náo poder realizar compras, respondeu:

Na verdade nós tivemos essa discussáo interna, mas superamos rapidamente. Tecnicamente se eu vou até ali do outro lado da praça [Rivera] eu fiz uma viagem internacional, para todos os efeitos legais inclusive. Se eu saio daqui [Santana do Livramento/BR] atravesso a rua, eu estou em outro país que é o Uruguai, sujeito a uma ordem jurídica, inclusive, entăo năo há como negar que eu fiz sim uma viagem internacional. Entăo a gente superou essa questăo presumindo que toda pessoa que for declarar as compras tenham feito uma viagem internacional, assim os moradores [Santana do Livramento] poderăo sim comprar (CANAL 10 RIVERA, 2014).

A mensagem é valida para a Zona de Fronteira Brasil/Bolívia, na qual se localiza Corumbá/MS, suas dinâmicas se assemelham a fronteira citada pelo servidor da Receita Federal. Quando o boliviano e o brasileiro ultrapassam as "linhas" estatais (que no caso daquela zona fronteiriça está materializada pelo Posto da Receita Federal do Brasil) tecnicamente (fazendo uso do termo empregado pelo inspetor-chefe) realizam viagens internacionais (todos os dias tais movimentos ocorrem, diga-se de passagem).

Ademais, o cidadāo boliviano, que é um dos grandes consumidores do comércio corumbaense (de acordo com o entâo Secretário municipal de Indústria 
e Comércio), oficialmente é um estrangeiro, logo, isso nâo deveria ser fator impeditivo para o início das discussōes sobre as lojas francas, isto é, elemento que protelasse as operaçôes do Grupo de Trabalho. Bolivianos e brasileiros ao atravessarem as "marcas" estatais para consumir em ambos os "lados" da fronteira realizam viagens internacionais e tal infixidez cotidiana está contemplada no artigo $2^{\circ}$ da Portaria 307/2014:

Art. $2^{\circ} \mathrm{O}$ regime aduaneiro especial de loja franca, quando aplicado em fronteira terrestre, permite, a estabelecimento instalado em cidade gêmea de cidade estrangeira na linha de fronteira do Brasil, vender mercadoria nacional ou estrangeira a pessoa em viagem terrestre internacional [grifo nosso], contra pagamento em moeda nacional ou estrangeira (BRASIL, 2014).

As viagens internacionais terrestres săo inerentes aquela Zona de Fronteira Brasil/Bolívia, portanto, vender somente a estrangeiros năo seria um problema. Assim, qualquer pessoa que tenha interesse e possua dinheiro e possa efetuar pagamento à vista poderá adquirir produtos nos futuros equipamentos comerciais.

Aqui é necessário abrir um parêntese. Em julho de 2015 entrevistamos o Sr. Otávio Philbois, presidente do Sindicato do Comércio Varejista de Corumbá - SINDVAREJO (membro titular do GT estabelecido em decreto), este sabia que năo existiam restriçóes quanto a quem poderia ou nâo comprar em lojas francas. Informaçăo que o órgáo encarregado de coordenar o Grupo de Trabalho para a criaçáo e instalaçăo dos free shops, a Secretaria de Indústria e Comércio (conforme o decreto municipal n 1432/2014), nâo possuía.

Tal incongruência pode ser explicada pelo fato das redaçôes dos artigos 13 e 14 da Portaria $n^{0}$ 307/2014 serem providas de determinaçóes muito amplas, abrindo margem à inúmeras interpretaçōes e/ou porque os sujeitos envolvidos no processo náo estavam dialogando de maneira profícua. Nós acreditamos na segunda hipótese.

\subsection{CONCILIAR PARA CONCORRER?}

Outra questáo que diz respeito ao tema ora em discussăo está relacionada a inquietaçōes quanto à conciliaçăo do Regime Aduaneiro Especial de loja franca a outra área territorial aduaneira. De acordo com o Sr. Pedro Paulo:

A prefeitura quer que os free shops sejam inseridos no centro comercial, năo há uma área específica, vemos dessa forma para fortalecer o comércio. Naquele comércio da rua Frei Mariano [área central do perímetro urbano de Corumbá/MS], ou em qualquer outro lugar da cidade que tenha o potencial para ser uma loja free shop. Se a gente instalar seja na fronteira, ou outro local específico, que vá ser estabelecido uma Zona Franca, acreditamos que náo vai fortalecer o mercado local. A gente vai abrir uma concorrência para o comércio local, com a abertura de megas lojas, e aí detona o comércio, mata o comércio local. É uma concorrência desleal. Que se crie dentro das cidades, como é o caso das Áreas de Livre Comércio [grifo nosso], onde a cidade inteira está supostamente liberada pra essa questăo, onde existe as fronteiras de controle. Por que Corumbá/MS, por ser uma fronteira praticamente conectada, é uma fronteira de livre passagem, năo tem um controle alfandegário de saída e entrada ${ }^{11}$.

11 Entrevista realizada no dia 29/09/2015. 
Logo, para o entâo Secretário de Indústria e Comércio, a intençăo era que fosse possível à coexistência do regime de loja franca com uma Área de Livre Comércio (ALC). Esta parecia ser a maior das preocupaçōes.

É preciso sublinhar que as ALCs sâo contempladas por um regime jurídico tributário privilegiado que favorece as atividades de indústrias e de comércio. Em consonância com Eusébio (2011), as empresas situadas em Áreas de Livre Comércio, no que concerne ao Imposto sobre Circulaçăo de Mercadorias e Prestaçăo de Serviços (ICMS), podem obter uma reduçâo final de carga tributária de $40 \%$ a $65 \%$ em funçáo da isençâo de tributos estaduais em remessas na Unidade Federativa e interestaduais, no crédito concedido ao contribuinte que adquire mercadorias, bem como:

Os benefícios fiscais se estendem aos tributos federais. As aquisiçóes de mercadorias por contribuintes situados em ALCs săo totalmente desoneradas de PIS/COFINS [Programa de Integraçấo Social/Contribuiçăo para o Financiamento da Seguridade Social], o que significa uma reduçăo de 9,25\% no preço de custo de todas as mercadorias e que deve constar expressamente na nota fiscal. A entrada de mercadorias nas Áreas de Livre Comércio, destinadas ao consumo, venda ou industrializaçăo, ficam isentas, ainda, do Imposto de Importaçăo e sobre Produtos Industrializados (IPI) (EUSÉBIO, 2011, p. 117).

As Áreas de Livre Comércio tem uma ampla abrangência no que diz respeito aos privilégios tributários e sâo instituídas e regidas por lei federal ${ }^{12}$. Aqui destaca-se que o Deputado Federal Dagoberto Nogueira propôs por meio do Projeto de Lei 533/2015 a criaçāo de Áreas de Livre Comércio para os Municípios de Corumbá/MS e Ponta Poră/ MS. O projeto já foi aprovado em cinco comissóes com caráter conclusivo, isto é, o projeto foi aprovado apenas pelas comissōes designadas para analisá-lo, dispensada a deliberaçăo do Plenário. O último parecer, encaminhado pela Comissâo de Constituiçâo e Justiça e de Cidadania (CCJ), foi dado no dia 17 de abril de 2018. Em entrevista concedida a rádio Cidade Branca dois dias após a aprovaçăo pela CCJ, o proponente declarou:

Olha nós conseguimos que esse projeto meu que é de 2015 passasse por cinco comissōes e essas comissōes todas foram aprovadas por unanimidade [...] Săo vários os deputados tentaram [...] e agora nós conseguimos com que ela fosse terminativa nas comissôes e aqui na câmara, foi aprovada ontem [17/04/18], ela já foi ao senado. Agora [...] a classe política tanto de Corumbá quanto de Ponta Porá, nós temos que fazer uma "pressăozinha" em nossos três senadores ${ }^{13}$ para que eles também nos ajude lá no senado. Eu tenho uma audiência marcado com o senador Eunício [Eunício Lopes de Oliveira], que é o presidente do senado hoje, para eu pode tratar desse assunto com ele, para eu pedir ajuda dele para que ele também faça terminativa nas comissōes e năo leve a plenário. E aí vai para sançăo do presidente e eu acredito que nâo teria problema se náo incluir outros municípios, se năo modificarem o projeto como ele está. Eu copiei o projeto de Manaus e como deu um bom desenvolvimento para Manaus, que levou indústria, que levou comércio, levou desenvolvimento, levou

12 No Brasil existem quatro territórios aduaneiros que se configuram como ALCs: 1) Área de Livre Comércio no município de Tabatinga, no Estado do Amazonas - Lei n 7.965, de 22 de Dezembro de 1989; 2) Área de Livre Comércio de Guajará-Mirim, no Estado de Rondônia - Lei nº 8.210, de 19 de julho de 1991; 3) Área de Livre Comércio nos municípios de Boa Vista e Bonfim, no Estado de Roraima - Lei n 8.256, de 25 de novembro de 1991; e 4) Área de Livre Comércio nos municípios de Brasiléia e Cruzeiro do Sul, no Estado do Acre - Lei n 8.857, de 8 de março de 1994.

13 Os três eleitos pelo estado de Mato Grosso do Sul săo: Pedro Chaves, Simone Tebet, Waldemir Moka. 
geraçăo de emprego, você vê Manaus antes ALC e vê Manaus como é hoje, pujante, é uma outra cidade, cresceu muito, é esse que interesse que nós temos tanto em Corumbá como em Ponta Porá (CIDADE BRANCA, 2018).

Em agosto de 2017, o Sr. Otávio Philbois, presidente do SINDVAREJO, relatou-nos em entrevista que observava inúmeras dificuldades na tramitaçăo do projeto na Câmara dos Deputados em decorrência da resistência dos parlamentares do estado de Sâo Paulo que nâo viam com bons olhos a criaçấo de um mecanismo de concorrência a indústria paulista. No entanto, também no afirmou que seria importante à criaçấo de uma ALC, pois para o líder sindical inúmeras empresas (de pequeno ou médio porte) instaladas no município de Corumbá/MS nâo teriam condiçōes de serem credenciadas como Free Shops por conta das exigências da Receita Federal para realizar a concessâo, logo, a ALC mitigaria efeitos prejudiciais aos empresários que năo conseguirem as certidōes ${ }^{14}$.

É preciso destacar que embora no âmbito municipal o Grupo de Trabalho criado náo tenha deliberado nada e na esfera federal a criaçấo da ALC esteja dependendo da discussâo no senado, a mobilizaçâo política no contexto estadual está adiantada. 0 Conselho Nacional de Política Fazendária - CONFAZ, na sua $212^{\mathrm{a}}$ reuniâo extraordinária realizada no dia 14 de janeiro de 2014, celebrou o Convênio ICMS 4. Este concedeu "[...] isençăo do ICMS em operaçóes realizadas por lojas francas localizadas nos aeroportos internacionais e em sedes de municípios caracterizados como cidades gêmeas de cidades estrangeiras" (CONFAZ, 2014, p. 1). Para o Sr. Otávio Philbois, a adesăo do estado de Mato Grosso do Sul ao convênio, isentando as lojas francas da cobrança do Imposto sobre Circulaçâo de Mercadorias e Serviços - ICMS é um grande avanço:

Eu achava particularmente, que todo esse andamento das lojas free năo iria ter um efeito prático mais efetivo enquanto tivesse o gravame do ICMS. Esse convênio [Convênio ICMS 4, de 15 de janeiro de 2014] que autoriza o estado de Mato Grosso do Sul a abrir măo da cobrança de ICMS nas lojas free deu uma vitaminada na diferença que ocorrerá no preço final ${ }^{15}$.

Ademais, para o líder sindical a isençăo na cobrança do ICMS em lojas francas vai alavancar e destravar a venda de produtos importados, visto estes dependerem da alíquota de imposto de importaçăo. Assim a perspectiva é de que num contexto geral haverá uma reduçăo de $10 \%$ a 15\% na cobrança de IPI, 17\%, no mínimo de ICMS, dependo a pauta pode chegar a $20 \%$, gerando um diferencial no preço final do produto nacional em torno de 30\%. Desta forma, há grande expectativa do setor e uma convergência açôes no que tange a futura conciliaçấo dos regimes aduaneiros de lojas francas e ALC.

O supracitado desejo, o adiantamento do tema (inclusive, o parecer da CCJ superou as expectativas) e o andamento das negociaçóes partidárias levam-nos a algumas

14 Em relaçăo à conciliaçăo do regime especial de Loja Franca com Área de Livre Comércio em fronteira terrestre, há o caso da Zona de Fronteira Brasil/Bolívia, respectivamente no estado de Rondônia e Departamento de Beni. O Poder Executivo estadual de Rondônia, no dia 28 de junho de 2014 sancionou a Lei n $n^{\circ} 3.364$ que autoriza a concessăo de isençăo total ou parcial do ICMS nas operaçóes realizadas por lojas francas em funcionamento no município de Guajará-Mirim/RO, cidade-gêmea com Guayaramerin (Departamento de Beni/Bolívia). A lei foi regulamentada pelo Decreto $n^{\circ}$ 18.897/2014, que instituiu o Regime Especial de Tributaçáo para loja franca instalada na Área de Livre Comércio de Guajará-Mirim (ALCGM). A estrutura estabelecida em Guajará-Mirim/RO pode ser o exemplo mais recente a ser seguido.

15 Entrevista realizada no dia 18/08/2017. 
questōes de extrema relevância. Se por um lado é fato que a criaçăo de políticas no Congresso Nacional é pautada pela concepçăo partidária, (ARRETCHE, 2012), por outro, é necessário considerar os ordenamentos (programas, leis, relatórios, etc.) pensados para as áreas de fronteira, analisar as características do território e verificar as dinâmicas de determinados sujeitos.

Desta maneira, é preciso destacar primeiramente que o aspecto favorável nesta relaçăo é que o GTI tem como uma das propostas de açăo para o desenvolvimento econômico da Faixa de Fronteira a criaçâo de regime especial e/ou diferenciado para exportaçóes e importaçóes entre micro e pequenas empresas. Entre as estruturas de fomento estăo as Áreas de Livre Comércio (as demais săo as Zonas de Integraçâo Fronteiriça e Zonas de Processamento de Exportaçōes).

Outrossim, ressaltamos que o Plano de Desenvolvimento e Integraçáo da Faixa de Fronteira/MS, publicado no ano de 2012 e elaborado pelo NFMS, apresenta como meta estratégica para simplificar e agilizar a formalizaçáo dos empreendimentos comerciais na Faixa de Fronteira, "[...] a criaçâo de novos centros comerciais e Free Shoppings nas cidades gêmeas" (MATO GROSSO DO SUL, 2012). Daí, a relevância dos órgăos que coordenam o Núcleo Regional sul-mato-grossense na cooperaçăo dos trabalhos do GT que versa sobre a instalaçâo de lojas francas em Corumbá/MS.

Todavia, na Zona de Fronteira da qual Corumbá/MS faz parte, os interessados também precisam levar em consideraçăo que às ALCs săo instrumentos articuladores dos níveis locais/regionais com o global e abrem precedentes para monopólios e, acima de tudo, para movimentar fluxos provenientes de atividades ilícitas (MACHADO, 2000), desta maneira, promovem evasăo de divisas e săo prejudiciais ao Estado. Durante a década de 1990, a implantaçăo de ALCs coincidiu com as políticas neoliberais que estavam sendo instrumentalizadas na América Latina e, sobretudo, beneficiaram a atuaçâo de poderosas transnacionais.

Além disso, o município de Corumbá/MS possuigraves problemas no que diz respeito à infraestrutura de transporte, fundamental na circulaçăo de mercadorias (LAMOSO, 2001; AUTOR, 2012). Condiçâo que por um lado desestimula a atraçăo do setor privado e por outro, com a instrumentalizaçâo do regime de ALC, os setores corporativos ao assumirem os riscos dos investimentos em uma regiăo com tais deficiências, estruturam o território de acordo com suas lógicas de mercado, implementando sistema logístico à revelia do Estado e da sociedade.

Bem como, é preciso que as entidades de classe, as lideranças políticas e os órgâos de planejamento de Corumbá/MS convoquem para a discussâo os sujeitos do "lado" boliviano daquela Zona de Fronteira, precipuamente, porque de acordo com as palavras do Deputado Dagoberto Nogueira, o projeto de lei que versa sobre a ALC para o município foi copiado da proposta que no passado contemplou Manaus/AM. A configuraçâo territorial na qual está inserida a cidade de Corumbá/MS é completamente distinta da realidade efetiva de Manaus e do estado do Amazonas. Destarte, ambos os "lados" devem estar conciliados ou dotado de coalizōes políticas para evitar anomalias futuras em decorrência do equivoco legislativo cometido pelo parlamentar que copiou diretrizes que deram certo num território na tentativa de implementá-la em outro. 


\subsection{OBSERVANDO O “LADO DE LÁ"}

Destaca-se que a discussáo de alguns sujeitos das classes dirigentes de Corumbá/ MS acerca da criaçáo de uma Área de Livre comércio, ao que parece também está relacionada às possibilidades de atraçấo de investimento para o "lado" brasileiro daquela fronteira frente a uma possível mudança das regras estabelecidas pelo governo do presidente Evo Morales no que diz respeito ao Regime Especial de Zona Franca da Bolívia. De acordo com o entăo Secretário de Indústria e Comércio da Prefeitura de Corumbá/ MS, o Sr. Pedro Paulo:

A gente sabe que os empresários que tem lojas no "lado de lá" da fronteira já estáo se movimentando, lutando dentro da Bolívia para a volta da Zona Franca, que foi extinta, "lá" [Puerto Quijarro, Arroyo Concepción] estăo sendo cobrados os impostos. Mesmo assim "lá" é favorável em relaçăo à gente, já tem quantos anos que o nosso comércio acaba tendo uma concorrência, náo é uma concorrência desleal, porque temos que ir lá, agora náo sei se com a instalaçăo de várias lojas [francas] e tal e uma pressáo do lado da Bolívia e volta a ser zona franca, de repente começa ser desfavorável o consumo ${ }^{16}$.

Logo, a criaçâo de território especial classificado como Área de Livre Comércio também se justificaria, pois existe receio quanto à "volta" do antigo Regime Especial de Zona Franca que contemplaria os estabelecimentos comerciais localizados em Puerto Quijarro/Arroyo Concepción. No entanto, é preciso sublinhar que essas áreas aduaneiras especiais na Bolívia năo foram extintas, ocorreram modificaçôes no regime especial que trata das Zonas Francas em "território" boliviano. Por meio do Decreto Supremo ${ }^{\circ} 470$, de 7 de abril de 2010, o Estado Plurinacional da Bolívia criou um novo "Reglamento de Régimen Especial de Zonas Francas" [ Regulamento de Regime Especial de Zonas Francas], modificado posteriormente pelo Decreto Supremo n 2390 , de 3 de junho de 2015 que realizou incorporaçôes e modificaçóes redaçăo original.

O “Reglamento de Régimen Especial de Zonas Francas" trouxe disposiçóes quanto à criaçăo de Zonas Francas privadas e concessăo destas, estabeleceu critérios para apresentaçăo de projetos, para solicitaçăo de concessăo, criou um sujeito (Comité Técnico de Zonas Francas CTZF) para análise das solicitaçôes, determinou prazos para concessâo (cinco anos para Zona Franca comercial, com possibilidades prorrogaçáo por mais cinco e dez anos para Zona Franca industrial, podendo ser prorrogado por mais cinco), determinou para os concessionários a criaçăo de bancos de dados para controle de estoques, a cobrança de tributos sobre importados e, entre outras questóes, versa sobre a possibilidade de criaçăo de empresas públicas ou mistas para administrar as Zonas Francas (BOLÍVIA, 2010). Em outras palavras, o Estado boliviano, com a publicaçăo do decreto, ampliou os mecanismos de regulaçâo e vigilância sobre os seus territórios aduaneiros especiais.

No caso da Zona de Fronteira Brasil/Bolívia em questăo, especificamente em Puerto Quijarro, o Decreto Supremo n $470 / 2010$ levou alguns estabelecimentos, que trabalhavam mediante as condiçóes do regime anterior de Zona Franca, a atuarem no regime comum, pois aparentemente náo atenderam as novas regras publicadas, todavia outras lojas que negociam mercadorias importadas permanecem no regime

16 Entrevista realizada em 29/09/2015. 
especial, precipuamente, aqueles de elevado capital. Ao que parece, o Estado boliviano tenta estar mais presente na fronteira, sobretudo, para arrecadar divisas e controlar os fluxos do comércio. Pretendem as instâncias públicas e privadas em Corumbá/MS com o desejo de criaçâo de Área de Livre Comércio o afastamento das instâncias estatais?

Tanto o presidente do Sindicato do Comércio Varejista de Corumbá - SINDVAREJO e a Secretaria de Indústria e Comércio (quando a pasta estava sob a direçấo do Sr. Pedro Paulo) estavam inquietos quanto à mobilizaçăo de alguns dos setores empresariais da Bolívia em direçâo ao regime especial de Zona Franca em Puerto Quijarro. Desse modo, para ambos a conciliaçăo de área de livre comércio com regime especial de loja franca iria criar condiçóes mais equitativas naquela fronteira ${ }^{17}$. Neste caso pensamos que equidade significaria igualar ou harmonizar condiçôes de comércio em ambos os "lados" da fronteira. Inserir mecanismos distintos com base nas premissas "territoriais" seria incoerência.

O novo regime especial de Zona Franca estatuído pelo Poder Executivo boliviano tem como objetivo controlar as atividades de comércio internacional e evitar evasáo de divisas, as Áreas de Livre Comércio promovem o oposto (MACHADO, 2000), assim como, é litigante em relaçáo ao Regime Aduaneiro Especial de Loja Franca, que embora beneficie o concessionário com isençăo tributária, tem como escopo controlar as operaçôes de comércio em pontos e zonas de fronteira, por isso a Receita Federal especifica como requisito a existência de um sistema informatizado de controle, como está previsto no artigo 6º inciso IV, da Portaria nº 307/2014.

Os setores brasileiros, da Zona de Fronteira questâo, envolvidos com as atividades de comércio poderiam pleitear aos órgăos federais a criaçâo de regime-jurídico territorial que possa ser harmonizado com as normas aduaneiras para territórios especiais do Estado boliviano e conciliá-lo com o regime de Loja Franca ${ }^{18}$. Aqui, é preciso destacar que em nosso trabalho de campo, realizado em novembro de 2017, obtivemos a informaçâo de que há uma articulaçâo de alguns segmentos empresariais da Província de Germán Busch na tentativa de estabelecer no "lado" boliviano da fronteira um regime aduaneiro especial semelhante à de Zona Econômica Especial (ZEE). Conforme as palavras do Gerente de Desenvolvimento Local da Prefeitura Municipal de Corumbá/ MS, o Sr. Raul Assef Castelāo:

Existe um diálogo da Prefeitura com o Comitê Institucional de Germán Busch que é a organizaçăo civil que está liderando esse processo de tentativa de criaçăo de uma Zona Econômica Especial aqui na fronteira. E o melhor escopo seria, nós temos aqui na regiấo as Lojas Francas ou área de livre comércio e do outro lado nós teríamos algo semelhante. Anossa intençáo enquanto secretaria de Indústria, comércio e Produçăo Rura ${ }^{19}$ náo é pensar no desenvolvimento de Corumbá/MS. Nós entendemos que pela conurbaçăo geográfica, nós só vamos avançar no desenvolvimento quando Ladário/ MS, Puerto Quijarro e Puerto Suárez também caminharem juntos conosco. ${ }^{20}$.

17 Declaraçóes proferidas em entrevistas realizadas em 23/07/2015 e 25/07/2015.

18 Existem exemplos de harmonizaçăo de legislaçăo para territórios de fronteira entre Brasil/Colômbia, Brasil/Paraguai, Brasil/Bolívia e Brasil/Uruguai. Para maiores detalhes verificar: Euzébio (2011), Costa, C. A. (2012) e Torrecilha (2013).

19 Atual da nomenclatura da Secretaria de Indústria e Comércio de Corumbá/MS.

20 Entrevista realizada em 17/11/2017. 
Ainda de acordo com o Sr. Raul Assef, a proposta de criaçăo da ZEE é uma sugestăo do Governo Central Boliviano, pois houve a percepçăo da movimentaçăo no Brasil acerca da criaçăo do regime aduaneiro especial de lojas francas. A fala do servidor público é importante porque (caso a informaçâo for verdadeira) nos incita a levantar uma questăo: como as instâncias de planejamento na Bolívia e/ou na Província de Germán Busch vâo conciliar os regimes de Zona Franca com o de ZEE e como posteriormente vai ocorrer à harmonizaçăo como os regimes especiais de lojas francas e área de livre comércio? Sáo estratégias comerciais distintas do ponto de vista jurídico e empírico (embora os Zonas Francas e ZEEs sejam conceitos próximos) ${ }^{21}$. Esta seria uma questáo que o Grupo de Trabalho poderia estar tentando responder caso estivesse em atividade.

\subsection{O GRANDE CAPITAL: DESFAZER E SEPARAR?}

Constatamos em nosso trabalho de campo que o Sindicato do Comércio Varejista de Corumbá - SINDVAREJO e a Secretaria municipal de Indústria e Comércio desejam a conciliaçăo dos regimes (loja franca e ALC), pois também há a tentativa de proteçáo aos comerciantes locais contra prováveis prejuízos frente à concorrência das empresas varejistas de elevado capital (a exemplo de Shopping China, Walmart, Carrefour e outros) que poderăo atuar no regime de lojas francas. Sublinha-se ainda que a Portaria n³07/2014 cita pessoa jurídica, sem mençăo a esta ser nacional ou internacional.

No decorrer do ano de 2017 as inquietaçóes se intensificavam. Primeiro porque a Receita Federal, até o mês de agosto, năo havia apresentado lista negativa de bens comercializáveis, o que abria a possibilidade para se vender tudo o que a lei năo proibia. Segundo, pois restavam dúvidas a respeito de como seria regulado o sistema de tributaçâo municipal com a instalaçáo do Regime especial de Loja Franca e posteriormente sua harmonizaçăo ao regime de ALC. Em consonância com o Sr. Otávio Philbois, uma proposta seria a criaçấo de "uma taxa de operaçấo municipal por metro quadrado para todas as empresas que eventualmente nāo tivessem tido alvará no município nos últimos cinco anos"22.

Os afligimentos supracitados e aqueles relacionados à concorrência dos estabelecimentos de elevado capital futuramente credenciados como lojas francas se ampliaram após as informaçôes da Receita Federal acerca do patrimônio líquido que os estabelecimentos comerciais teriam que possuir para poderem atuar.

No dia 07 de dezembro de 2017 foi realizado o seminário promovido pela Uniâo dos Legisladores e Legislativos Brasileiros (Unale) que foi palco de esclarecimentos sobre a lei $n^{\circ} 12.723 / 2012$ e de sua regulamentaçáo pela Receita Federal. O evento ocorreu um dia antes do término do prazo para envio de propostas a fim de subsidiar a elaboraçâo da Instruçâo Normativa que atualmente dispóe sobre as atividades relacionadas ao regime de lojas francas, quando localizadas em fronteiras terrestres. Durante a reuniâo pública os representantes da Receita Federal apontaram que a intenção era estabelecer como critério para credenciamento no regime somente estabelecimentos

21 Para maiores detalhes sobre Zonas Francas e Zonas Econômicas Especiais, consultar: PINTO (1992); LIANG (1999) e ARITENANG (2009).

22 Entrevista realizada no dia 18/08/2017. 
comerciais com no mínimo de R\$ 5.000 .000 (cinco milhóes de reais) de patrimônio líquido.

Em janeiro de 2018, tivemos mais uma vez a oportunidade de entrevistar o presidente do SINDVAREJO. De acordo com o Sr. Otávio Philbois, que participou do seminário supra indicado, a proposta oriunda da Receita Federal năo agradou. Este critério favoreceria empresas com elevado capital e excluiria as pequenas e médias do processo, haja visto a possibilidade de muitas náo serem dotadas de tal capital.

Opiniâo compactuada pelo Sr. Aldir Comunello, $2^{\circ}$ vice-presidente da Associaçâo Comercial de Corumbá - ACIC. Este sindicalista nos informou, também em janeiro de 2018, que as propostas enviadas pelo sindicato dos comerciários e pela associaçáo comercial de Corumbá/MS na consulta pública realizada pela Receita Federal coincidiam no sentido de preservar o comerciante local. As propostas encaminhadas foram: a) concessâo ao regime de lojas francas, as empresas que já estivessem atuando, no mínimo, 10 anos nas cidades de fronteira, independentemente, do patrimônio líquido e b) concessâo aos estabelecimentos que repassassem a Uniâo uma garantia com valor mínimo entre R\$ 250.000 (duzentos e cinquenta mil) e R\$ 1.000.000 (um milhăo de reais), sob a forma de cheque calçăo.

Esta questăo de classe ficou ainda mais indefinida, pois no dia 16 de março de 2018 foi publicada a Instruçăo Normativa no 1799 da Secretaria da Receita Federal que estabeleceu normas complementares à Portaria n³07/2014. No que tange as condiçôes e requisitos para a concessăo das empresas ao regime, o artigo $5^{\circ}$ da primeira, no inciso $\mathrm{X}$ e parágrafo $3^{\circ}$, define que devem possuir patrimônio líquido igual ou superior a $\mathrm{R} \$$ 2.000.000,00 (dois milhóes de reais) e se caso nâo atender ao requisito:

[...] poderá obter a concessăo desde que mantenha garantia em favor da Uniăo em valor igual ou superior a R\$ 2.000.000,00 (dois milhóes de reais); ou no valor correspondente à diferença entre o seu patrimônio líquido e esse limite, sob a forma de depósito em dinheiro, fiança bancária ou seguro aduaneiro (BRASIL, 2018).

Esta deliberaçăo passou ao largo daquelas pensadas pelo SINDVAREJO e ACIC de Corumbá/MS. Em janeiro de 2018, os sindicalistas das mencionadas entidades nos informaram que caso a Instruçăo Normativa estabelecesse condiçóes adversas para que as empresas localizadas no município pudessem participar da concessâo, a soluçáo seria pressionar o poder público municipal para publicar uma lei desautorizando a instalaçăo do regime aduaneiro em Corumbá/MS ou lei que viabilize a segregaçăo espacial e distanciamento das grandes empresas (credenciadas no regime de loja franca) da área na qual se localiza o centro comercial.

As intençōes supramencionadas pelos dirigentes, a nosso ver, săo pífias. Primeiro porque há o envolvimento da cena política e dificilmente o poder executivo e a câmara municipal văo discutir e criar lei que impeça a instalaçăo do regime aduaneiro de loja franca (já autorizado no município), justamente no momento em que a Instruçăo Normativa $n^{\circ} 1799$ da Secretaria da Receita Federal foi publicada, sinalizando que empresas com capital considerável podem se instalar em Corumbá/MS, algo que se transforma em capital político (eleitoral especificamente) para os parlamentares

Segundo, pois empresas com elevado capital exigem dos órgâos públicos vantagens locacionais e financiamento de infraestrutura com recursos públicos e assim o fazem 
porque financiam campanhas. Assim, os grandes grupos também possuem interesses de classe e fazem pressáo ao poder público. Geralmente, é o parlamentar (deputado estadual, prefeito, vereador e outros) que "prepara o terreno" para a instalaçấo dos grandes grupos. É inconcebível pensar que as pressōes dos agentes locais do comércio vấo influenciar a decisâo do poder público frente empresas de grande porte que podem gerar mais empregos (e consequentemente mais votos) do que todos os demais estabelecimentos juntos. Em nossa opiniâo açôes de impingindo limites de atuaçâo e obliteraçăo de tais empresas, via lei municipal, é praticamente impossível.

A soluçâo nâo está na publicaçâo de leis que desautorizem o novo regime ou distanciem essas empresas do centro comercial. Mas sim a criaçâo de programas e normas que regulem os estabelecimentos dessas empresas com elevado capital no sentido de promoverem a expansăo do comércio naquela fronteira, de estimularem a criaçăo de outras demandas no setor de serviço e possibilitar que o poder público e o setor privado produzam outros programas de qualificaçăo, inclusăo social e fóruns de debate. Para tal os membros das sociedades das quatro cidades que compóem a Zona de Fronteira em questâo precisam participar dos processos decisórios. As políticas de ordenamento do território em qualquer município daquela fronteira devem ser pensadas em diálogos amiúdes de ambos os "lados".

\section{CONSIDERAÇÕES FINAIS}

A Receita Federal é um organismo que possui uma lógica macroterritorial de planejamento, quando pensa nas regulaçōes o faz para proteger o "território nacional", aparentemente, nâo considera as particularidades territoriais, assim, săo os agentes locais os responsáveis pela sinalizaçâo das singularidades do território. No caso da Zona de Fronteira Brasil/Bolívia e desta discussâo, os agentes locais săo os sujeitos que compóem e participam do setor de comércio de ambos os "lados".

O Grupo de Trabalho, instituído pelo Decreto municipal $n^{0} 1.432 / 2014$, seria um ótimo instrumento para articular os diversos setores que atuam no comércio daquela Zona de Fronteira e impingir pressōes aos organismos federais. Todavia, o GT, passado quase quatro anos de sua criaçáo, até o momento em que realizamos o nosso último trabalho de campo (janeiro de 2018) năo havia iniciado as atividades.

Aparentemente, alguns sujeitos em Corumbá/MS năo estăo dispostos a discutir com o "outro lado da fronteira" questóes que săo inerentes a ambos os "lados". O que constamos por ora é que as divergências entre a lógica macroterritorial de intervençáo da Receita Federal e realidade do território năo estăo sendo debatidas, logo, tal dissonância se nâo for refletida pode acarretar alguns encaminhamentos que, na nossa opiniâo, náo seráo benéficos nem para os comerciantes brasileiros muito menos para os bolivianos. A instrumentalizaçâo do Grupo de Trabalho seria fundamental como mecanismo subsidiário para os órgáos públicos federais, em especial a Receita Federal, realizarem as adequaçóes normativas necessárias à realidade daquela Zona de Fronteira, permitiria aos envolvidos transformar a escala local em arena política, nesse caso, todos os sujeitos da Zona de Fronteira devem participar.

Desta maneira, faz-se necessário a operacionalizaçâo do Grupo de Trabalho ou de uma comissâo binacional para que os participantes possam debater: 
a. Formas de harmonizaçăo jurídico-territorial entre Brasil e Bolívia que possibilitem a conciliaçăo entre o regime de Loja Franca, Zona Franca, Zona Econômica Especial e com a estrutura de Área de Livre Comércio (haja vista isso ser, aparentemente, um desejo de alguns sujeitos do "lado" brasileiro);

b. A formulaçăo de assessoria jurídica para pensar em alternativas, caso os regimes nâo possam a ser conciliados;

c. A formaçăo de subgrupos de trabalho, formados por sociólogos, geógrafos, juristas, antropólogos, historiadores, economistas, analistas em relaçóes internacionais e outros para pensar/elaborar políticas públicas que possam estar associadas à rede de relaçôes que poderá por ser estabelecida com a instalaçấo do regime de Lojas Francas, especialmente no que tange a geraçâo de empregos e qualificaçăo profissional;

d. A criaçăo de subgrupos de trabalho para discussâo/elaboraçăo de diagnósticos (estudos) que identifiquem as futuras inarmonias na relaçăo entre regime aduaneiro comum e especial, bem como, para elaborar planos (de prevençâo e emergência) que visem mitiga-las;

e. A constituiçấo de subgrupos de trabalho para realizar levantamentos a respeito de quais serăo as consequência em decorrência da concessăo de empresas de grande capital ao regime de loja franca;

f. O estabelecimento de subgrupos de trabalho para discutir a publicaçăo de normas que regulem a atuaçăo de empresas de grande capital no que tange a: direitos trabalhistas, política de preservaçâo e/ou conservaçâo do meio ambiente, retorno social no setor da educaçấo e cultura (exigindo que a porcentagem dos recursos investidos sejam de acordo com os lucros reais dessas empresas), discussâo pública e transparente dos critérios para estabelecimento de desoneraçăo tributária por parte dos órgăos públicos (municipais e estaduais), criaçăo de fundo municipal/transfronteiriço destinado a manutençăo de instâncias que tenham como objetivo criaçâo e execuçâo de políticas públicas para a Zona de Fronteira Brasil/Bolívia;

g. A elaboraçâo de subgrupos de trabalho para verificar quais estabelecimentos podem ser concessionários do regime de Loja Franca naquela Zona de Fronteira, bem como, pensar em consórcio de empresas (com acionistas brasileiros e bolivianos) para participar do processo de credenciamento no regime de lojas francas;

h. A elaboraçáo de catálogo dos produtos comercializados nos estabelecimentos das cidades-gêmeas que compôem aquela Zona de Fronteira. Instrumento importante para auxiliar a Receita Federal quanto à confecçấo da lista negativa dos bens;

i. As lacunas da Portaria n 307/2014, como, por exemplo, a inexistência de isençăo tributária para bens nacionais, o artigo 13 especifica produtos importados;

j. A realizaçăo das reuniôes participativas para recolher subsídios junto aos diversos segmentos da sociedade daquela fronteira. Metodologia importante, pois possibilita a aproximaçấo da pluralidade de ideias dos cidadăos e das entidades em geral interessados no assunto com a concepçâo técnica dos órgăos de planejamento; 
k. Os prazos para apresentaçăo, aos setores sociais interessados, dos relatórios referentes ao processo (Este procedimento é importante para a realizaçâo das reuniōes participativas); e

1. A realizaçấo das audiências públicas para expor os resultados.

Esses sâo alguns pontos que poderiam ser debatidos, sâo questôes gerais que possuem espraiamentos por conta das especificidades. Bem como, o Grupo de Trabalho ou comissăo binacional, poderá realizar diálogo mais consistente com os órgăos federais, especialmente a Receita Federal. Esta infere no território por meio de política do tipo Top-down, ou seja, de cima para baixo, porque dá primazia a escala estatal e centraliza a política de tomada de decisôes, método de açâo que no caso das cidades-gêmeas acarreta dissonâncias, visto a escala do território (micro) atravessar normas mais generalizantes. 


\section{REFERÊNCIAS}

ARRETCHE, M. Democracia, federalismo e centralizaçāo no Brasil. Rio de Janeiro: FGV, 2012.

ARITENANG, A. F. A comparative study on free trade zone: development through spatial economic concentration. Jurnal Perencanaan Wilayah dan Kota. Vol. 20, n. 2 Agustus, 2009.

BRASIL. Casa Civil. Subchefia para assuntos jurídicos. Decreto-Lei n ${ }^{0}$.455, de 7 de abril de 1976.

BRASIL. Constituiçâo (1988). Constituiçâo da República Federativa do Brasil: Texto constitucional promulgado em 5 de outubro de 1988 com alteraçóes adotadas pelas Emendas constitucionais n 1/92 a 32/2001 e pelas Emendas Constitucionais de Revisâo no 1 a 6/94. Brasília: Senado Federal, Subsecretaria de Ediçōes Técnicas, 2001.

BRASIL. Ministério da Integraçăo Nacional. Proposta de reestruturaçăo do Programa de Desenvolvimento da Faixa de Fronteira. Brasília: MIN, 2005.

BRASIL. Ministério da Fazenda. Portaria MF n 440, de 30 de julho de 2010.

BRASIL. Grupo de Trabalho Interfederativo de Integraçăo Fronteiriça. Bases para uma Proposta de reestruturaçāo do Programa de Desenvolvimento da Faixa de Fronteira. Brasília: GTIIF, 2010.

BRASIL. Casa Civil. Subchefia para assuntos jurídicos. Lei 12.723, de 09 de outubro de 2012.

BRASIL. Ministério da Integraçâo Nacional. Portaria n 125, de 21 de março de 2014. Republicada em 26 de março de 2014.

BRASIL. Ministério da Fazenda. Portaria MF nº 307, de 17 de julho de 2014 (b).

BRASIL. Ministério da Fazenda. Portaria MF n³20, de 22 de julho de 2014 (c).

BRASIL. Ministério da Fazenda. Portaria MF nº 415, de 26 de junho de 2015.

BRASIL. Ministério da Fazenda. Portaria MF n² 289, de 30 de Junho de 2016.

BRASIL. Ministério da Fazenda. Portaria MF n³07, de 29 de junho de 2017.

BRASIL. Ministério da Fazenda. Instruçâo Normativa RFB Nº1799, DE 16 de março de 2018.

BOLÍVIA. Reglamento de Régimen Especial de Zonas Francas. Decreto Supremo n 470, de 07 de abril de 2010. 
BOLÍVIA. Decreto Supremo n²390, de 03 de junho de 2015.

CÂMARA DOS DEPUTADOS. PROJETO DE LEI No 6.316/2009. Disponível em:http://www.camara.gov.br/proposicoesWeb/fichadetramitacao?idProposicao=457359. Acesso em 15 out. 2013.

CANAL 10 RIVERA. Inspector Adilson Valente - Jefe Receita Federal Santana do Livramento. In:〈https://www.youtube.com/watch?v=jMy5UWV-Uks>. Acesso em 25 jan. 2015.

CIDADE BRANCA. Exclusivo: Dagoberto fala sobre área de livre comércio aprovada em Corumbá, 2018. Disponível em:< http://www.cidadebranca.com.br/exclusivo-dagoberto-fala-sobre-area-de-livre-comercio-aprovada-em-corumba/>. Acesso em 20 abr. 2018. CONFAZ. Conselho Nacional de Política Fazendária. CONVÊNIO ICMS 4, de 15 de janeiro de 2014.

COSTA, C. A. A construçâo da concepçâo de natureza na fronteira de Ponta Porâ/BR Pedro Juan Caballero/PY e a produçâo do urbano. Dissertaçâo (Mestrado em Geografia) - Faculdades de Ciências Humanas, Universidade Federal da Grande Dourados, 2012.

EUSÉBIO, E. F. Fronteira e Horizontalidade na Amazônia: As cidades-gêmeas de Tabatinga (Brasil) e Letícia (Colômbia). Dissertaçâo (Mestrado em Geografia) - Faculdades de Filosofia, Ciências e Letras, Universidade de Săo Paulo, 2011.

AUTOR. O Título da referência foi omitido para nâo haver identificaçâo da autoria em decorrência do parecer às cegas. 2015.

AUTOR. O Título da referência foi omitido para nāo haver identificação da autoria em decorrência do parecer às cegas. 2012.

G1. Governo recua e suspende reduçâo de cota de importaçâo por terra. 2014. Disponível em:<http://g1.globo.com/economia/seu-dinheiro/noticia/2014/07/governo-recua-e-suspende-reducao-de-cota-de-importacao-por-terra.html>. Acesso 10 Ago. 2014.

LAMOSO, L. P. A exploração do minério de ferro no Brasil e no Mato Grosso do Sul. Tese (Doutorado em Geografia) - Faculdades de Filosofia, Ciências e Letras, Universidade de São Paulo, 2001.

LIANG, Z. Foreign investment, economic growth, and temporary migration: The case of Shenzhen special economic zone, China. Development and Society, 28.1, 1999.

MACHADO, L. O. Limites e Fronteiras: da alta diplomacia aos circuitos da ilegalidade. Revista Território, Rio de Janeiro, ano V, n 8, pp. 7- 23, jan./ jun., 2000.

MATO GROSSO DO SUL. Governadoria Municipal de Corumbá/MS. Gabinete do prefeito. Decreto $n^{0} 1.432$, de 21 de outubro de 2014. 
MATO GROSSO DO SUL. Núcleo Regional de Integraçăo da Faixa de Fronteira do Estado de Mato Grosso do Sul NFMS. Plano de Desenvolvimento e Integraçâo da Faixa de Fronteira/MS, 2012.

RADIOCULTURA. Prefeitos de Foz e Cidade do Leste tentarâo suspender diminuiçăo de cota. 2014. Disponível em: <http://www.radioculturafoz.com.br/prefeitos-de-foz-e-cidade-do-leste-tentarao-suspender-diminuicao-de-cota/\#.WaCFDGdhkdU〉. Acesso em 4 ago. 2017.

SILVA, T. V.; PRADO, H. S. A. Lojas francas na fronteira: breves apontamentos sobre a Lei n. 12.723/2012. Revista Eletrônica Direito e Política, Programa de Pós- Graduaçáo Stricto Sensu em Ciência Jurídica da UNIVALI, Itajaí, v.9, n.1, 1 quadrimestre de 2014. Disponível em: www.univali.br/direitoepolitica. Acesso em: 20 out. 2014.

SOMBRA SARAIVA, J. F. Federalismo e Relaçōes Internacionais do Brasil. In:

ALTEMANI. H; LESSA A. C. (Orgs.) Relaçōes Internacionais do Brasil: Temas e Agenda. Sâo Paulo: Saraiva, 2006.

PERPÉTUO, R. O. “Estudo de caso - Município de Belo Horizonte”. In: Marcovitch, J. (Org.) Relaçóes Internacionais de Âmbito Subnacional: A Experiência de Estados e Municípios no Brasil. Sâo Paulo: Instituto de Relaçôes Internacionais-Universidade de Sáo Paulo, 2014.

POULANTZAS, N. O Estado, o poder, o socialismo. $3^{\circ}$ ed. Rio de Janeiro- RJ. Brasil. Trad. Rita Lima, 2000.

PINTO, E. R. F. Zona Franca de Manaus e o desenvolvimento regional. Săo Paulo em Perspectiva, 6.1-2. 1992.

TORRECILHA, M. L. A gestâo compartilhada como espaço de integraçâo na fronteira: Ponta Porâ (Brasil) e Pedro Juan Caballero (Paraguai). 2013. Tese (Doutorado em Geografia) - FFLCH - USP, Universidade de Săo Paulo. 